\title{
Combined Butyric Acid and Methane Production from Grass Silage in a Novel Green Biorefinery Concept
}

\author{
Jörg Steinbrenner ${ }^{1}$ D $\cdot$ Joachim Mueller ${ }^{2} \cdot$ Hans Oechsner $^{1}$
}

Received: 14 March 2021 / Accepted: 25 October 2021 / Published online: 5 November 2021

(c) The Author(s) 2021

\begin{abstract}
In a Green Biorefinery, grass silage can be a source for lactic acid, proteins, amino acids and fibres. Processing residues can be used for anaerobic digestion and methane production. But by changing the ensiling conditions, butyric acid fermentation can be achieved. That makes grass silage also a potential substrate for a combined butyric acid and methane production. The objective of this study was to determine the potential of butyric acid production at different ensiling conditions applied to grass and measuring the methane yield potential of solid residues after a separation step. The highest butyric acid concentration in the produced press juice was $20.1 \pm 4.5 \mathrm{~g} \mathrm{~kg}^{-1}$ and was achieved by carbonated lime addition and a reduced dry matter content after 90 days at mesophilic storage conditions. This resulted in a theoretical butyric acid yield of $332 \mathrm{~kg} \mathrm{ha}^{-1} \mathrm{a}^{-1}$. For the fibrous leftover press cake, a theoretical methane production potential of $2778 \mathrm{~m}_{\mathrm{CH} 4}^{3} \mathrm{ha}^{-1} \mathrm{a}^{-1}$ was reached. The results show that theoretically a combined production of butyric acid and methane can be realised in a Green Biorefinery concept.
\end{abstract}

\section{Graphic Abstract}
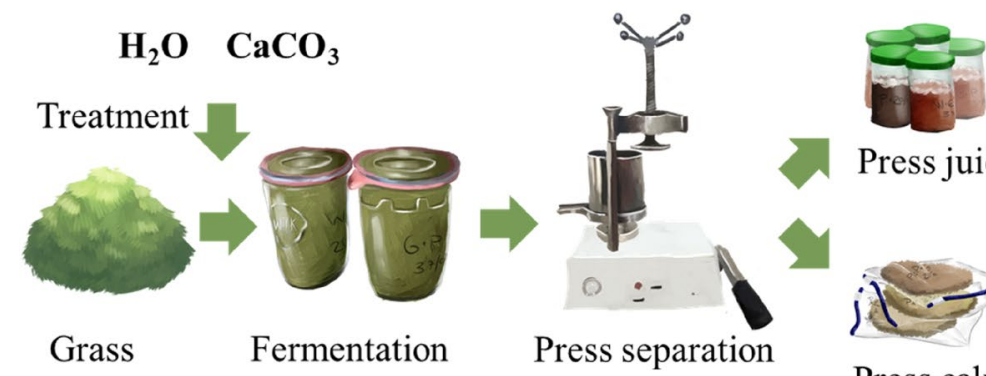

Press juice

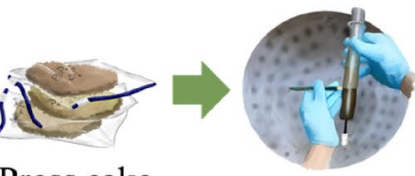

Press cake

Biogas yield test

Keywords Biobased chemicals $\cdot$ Bioeconomy $\cdot$ Anaerobic digestion $\cdot$ Ensiling $\cdot$ Biogas

Jörg Steinbrenner

joerg.steinbrenner@uni-hohenheim.de

Joachim Mueller

joachim.mueller@uni-hohenheim.de

Hans Oechsner

hans.oechsner@uni-hohenheim.de

1 State Institute of Agricultural Engineering and Bioenergy, University of Hohenheim Stuttgart, Garbenstraße. 9, 70599 Stuttgart, Germany

2 Institute of Agricultural Engineering, Tropics and Subtropics Group (440e), University of Hohenheim Stuttgart, Garbenstraße. 9, 70599 Stuttgart, Germany

\section{Statement of Novelty}

The specific objective of this research was to investigate whether the ensiling process is suitable for butyric acid production. Therefore, different ensiling conditions were evaluated for butyric acid production which will create additional value on the farm. The residues, which are not used for the production of butyric acid, will not be wasted but used as substrate for biogas production. The information we provide will help to open up new processes and alternative raw materials for butyric acid production und using the leftover 
residues for methane production through anaerobic digestion. The results are novel and significant to the combined fields of anaerobic digestion and Green Biorefineries and will be viewed by a scientific audience but it is also of great interest to the bioeconomic sector.

\section{Introduction}

In $2017,5.38$ billion hectares were considered as agricultural land and used for the production of food and goods worldwide. This includes cropland with 1.7 billion hectares and permanent meadows and pastures with 3.66 billion hectares, which means that $68 \%$ of the agricultural land worldwide is dominated by grassland [1]. This grassland can deliver a huge amount of biomass and contributes not only to the food production through animal husbandry, but also has ecological functions. Moreover, this high amount of biomass has a huge potential for energy production through anaerobic digestion.

However, grass can also be used for higher quality processing than energy production. According to bioeconomic approaches, the production of volatile fatty acid acids could lead to a higher added value on the farm. In this approaches, carboxylates formed during the anaerobic degradation of biomass could serve as intermediate platform chemicals [2]. The remaining biomass can be used to generate methane in an anaerobic digestion plant. Right now, the main focus for optimization of anaerobic digestion plants is on upgrading existing plants for demand oriented biogas production [3-5]. Another approach to increase the added value in the future could be the Green Biorefinery. In this concept, silages, which are one of the most common feedstock in agricultural biogas plants especially in Germany, could be used as a source for valuable chemicals like lactic acid or proteins [6-8]. Green Biorefineries are already recognised for the extraction of valuable proteins from grass and clover and making them available for the nutrition of monogastric animals and ruminants, as an alternative to the use of soybean [9]. Another option could be the generation of organic acids through ensiling [8]. In both cases, the extraction of the desired ingredients through a separation step is necessary. In which the used separation method and the silage quality have a great impact on the separation efficiency [10]. The ensiling process is a lactic acid fermentation, but by changing the ensiling conditions, the lactic acid fermentation can switch to a butyric acid fermentation during fermentation [11]. For the sole production of biogas or the use as animal feedstock, butyric acid formation during fermentation is undesirable. High energy losses occur during ensiling, and it is non-edible for animals due to the high butyric acid concentrations. But in the case of targeted production of butyric acid for use in the chemical industry, it could potentially be a low-cost alternative. Butyric acid is used in a wide range of products. It is a precursor for biofuel production, like biobutanol, in the pharmaceutical and chemical industries, e.g. for plastic production or butyric acid esters can be used in food and cosmetic industry as flavouring or fragrant agents [12]. Having a closer look on the fermentative production of butyric acid, one of the main challenges in butyric acid production is a self-inhibitory effect because of a decreasing $\mathrm{pH}$-value. In addition, the formation of by-products such as acetic acid is of concern, as it is difficult to separate. Furthermore, low butyric acid concentrations followed by high product recovery costs and a limited productivity are major challenges, too. [13]. In research, biotechnological butyric acid production is widely based on glucose, but has also been performed with agricultural raw materials like wheat straw. However, these substrates need pre-treatment before fermentation, like steam explosion and hydrolysis to generate sugars like glucose or xylose for a butyric acid fermentation [13, 14]. Additionally, the usage of xylose e.g. by Clostridium tyrobutyricum is inhibited, but making the usage of xylose possible is part of approaches to optimize the butyric acid fermentation [15]. It is also mentioned, that the usage of glucose, starch or other agricultural derived products is not feasible, because of the high production costs and its competition with the usage for food production [16].

The objective of this research was to determine the natural potential for butyric acid production from grass, further measuring the methane formation potential of the remaining residues and implementing the results into a Green Biorefinery concept.

\section{Materials and Methods}

\section{Raw Material}

The fresh grass was harvested on 23 May 2018 at the 'Unterer Lindenhof' (Eningen Unter Achalm, Germany), an agricultural research station of the University of Hohenheim. The grass was chopped by a forage harvester to $8 \mathrm{~mm}$ theoretical length of cut. During harvest no ensiling additives were added.

At 'Unterer Lindenhof' an average annual precipitation of $770 \mathrm{~mm}$ and an average temperature of $11.6{ }^{\circ} \mathrm{C}$ were measured for the last five years [17]. The grassland can be considered as intensively used grassland, as it is cut up to four times a year and fertilized with digestate from a nearby agricultural anaerobic digestion plant.

\section{Fermentation Treatments}

Glass jars with a volume of $1.5 \mathrm{~L}$ (Weck GmbH und Co. $\mathrm{KG}$, Wehr-Oeflingen, Germany) were used for ensiling and closed with a sealing ring and a glass lid with 3 clips.

The conducted treatments are shown in Table 1. They consist of a control variant (C), a variant with carbonated 
lime $\left(\mathrm{CaCO}_{3}\right)$ addition as a $\mathrm{pH}$ buffer $(\mathrm{B})$, a variant with the addition of water $(\mathrm{W})$ and a variant from the combination of water and carbonated lime (WB). Both the addition of $\mathrm{CaCO} 3$ and the addition of water are aimed at creating conditions to allow the formation of butyric acid. Furthermore, two different storage temperatures were tested. This means that all treatments were performed two times and stored at $22 \pm 1{ }^{\circ} \mathrm{C}(20)$ and at $37 \pm 1{ }^{\circ} \mathrm{C}(37)$.

For filling the jars with chopped grass, $20 \mathrm{~kg}$ of grass was mixed and each jar was filled with the feedstock including the additives. $\mathrm{CaCO}_{3}$ and distilled water were added directly into the jars. When filling the jars, there was no headspace left. For the control treatments (C20, C37) a density of 186 $\mathrm{kg}_{\mathrm{TS}} \mathrm{m}^{-3}$ was achieved. Whereas for the other treatments the density differs according to the additives added (Table 1). The distilled water, $\mathrm{CaCO}_{3}$ and a combination of both was added to decrease the total solid (TS) content of the grass and to increase the buffering capacity. Jars without additives served as control treatment (Table 1).

For fermentation the jars were stored under two temperatures: (i) at $22 \pm 1{ }^{\circ} \mathrm{C}$ in an insulated storage room and (ii) at $37 \pm 1{ }^{\circ} \mathrm{C}$ in a water bath controlled by a circulation thermostat (Ecoline E200, Lauda Dr. R. Wobser GmbH \& Co. KG., Lauda-Koenigshofen, Germany). Temperature of the water bath was measured continuously by four temperature sensors (B+B Immersion sensor 0625142911, B\&B Thermotechnik $\mathrm{GmbH}$, Donaueschingen, Germany) and recorded with a data logger (Ebro EBi 40, Xylem Analytics Germany Sales GmbH \& Co. KG, Weilheim, Germany). While the temperature in the storage room was measured continuously with two temperature sensors (Testo TE Type K, Testo SE \& Co.KGaA, Titisee-Neustadt, Germany) and recorded by a data logger (Testo 176T4, Testo SE \& Co.KGaA, TitiseeNeustadt, Germany).

Table 1 Overview of the conducted treatments with the amounts of grass and additives added, as well as the achieved theoretical compaction in the glasses

\begin{tabular}{llllll}
\hline Treatment & $\begin{array}{l}\text { Grass } \\
\mathrm{g}\end{array}$ & $\begin{array}{l}\mathrm{CaCO}_{3} \\
\mathrm{~g}\end{array}$ & $\begin{array}{l}\text { Water } \\
\mathrm{g}\end{array}$ & $\begin{array}{l}\text { Target weight } \\
\mathrm{g}\end{array}$ & $\begin{array}{l}\text { Compaction } \\
\mathrm{kg}_{\mathrm{TS}} \mathrm{m}^{3}\end{array}$ \\
\hline $22 \pm 1{ }^{\circ} \mathrm{C}$ & & & & & \\
$\mathrm{C} 20$ & 750 & - & - & 750 & 195 \\
W20 & 500 & - & 250 & 750 & 130 \\
$\mathrm{~B} 20$ & 727 & 22.9 & - & 750 & 204 \\
WB20 & 485 & 15.3 & 250 & 750 & 141 \\
$37 \pm 1{ }^{\circ} \mathrm{C}$ & & & & & \\
$\mathrm{C} 37$ & 750 & - & - & 750 & 195 \\
W37 & 500 & - & 250 & 750 & 130 \\
$\mathrm{~B} 37$ & 727 & 22.9 & - & 750 & 204 \\
WB37 & 485 & 15.3 & 250 & 750 & 141 \\
\hline
\end{tabular}

$C$ untreated control, $W$ water addition, $B \mathrm{CaCO}_{3}$ addition, $W B$ combination of water and $\mathrm{CaCO}_{3}$ addition
According to the DLG guidelines for ensiling and testing of ensiling additives $[18,19]$ jars were successively opened after 3, 14, 30 and 90 days of fermentation. Each of the eight treatments was carried out in triplicate, three jars per treatment were opened at each opening date requiring 96 jars in total.

\section{Separation Procedure and Extraction Efficiency}

After ninety days of fermentation, samples of the ensiled grass were taken and separated with a tincture press (HPH 2.5, HAPA Fertigungstechnik, Germany) at $20 \mathrm{MPa}$ for $60 \mathrm{~s}$ into press cake and press juice.

\section{Specific Methane Yield Determination by Hohenheim Biogas Yield Test (HBT)}

The determination of the specific biogas yield (SBY) and the specific methane yield (SMY) was done with Hohenheim Biogas Yield Test (HBT), according to the VDI Guideline 4630 [20]. The gas yield was corrected for standard conditions $(273.15 \mathrm{~K}, 1013 \mathrm{hPa})$ and expressed in $\mathrm{m}^{3}$ per $\mathrm{kg}$ of volatile solids (VS). Further in this article, the measured specific biogas and methane yields are mentioned in relation to $\mathrm{m}^{3} \mathrm{~kg}^{-1}$.

The HBT was performed with glass syringes, these were filled with a standardized inoculum and the substrate to be tested. The filled syringes were placed in a climate chamber and digested at $37{ }^{\circ} \mathrm{C}$ for 35 days. A detailed description of the HBT system is given by Helfrich and Oechsner [21]. All samples were done in triplicates.

\section{Analytical Methods}

\section{Total Solids and Volatile Solids Determination}

The TS and VS of the samples were determined according to DIN EN 12,880, DIN EN 12,879. The samples were weighed and then dried overnight in a drying chamber at $65^{\circ} \mathrm{C}$ (UF450, Memmert $\mathrm{GmbH}$, Germany). Afterwards they were dried at $105^{\circ} \mathrm{C}$ (UF450, Memmert GmbH, Germany) to constant weight and weighed again to determine the TS. The VS was determined by burning the dried samples at $550{ }^{\circ} \mathrm{C}$ in a muffle furnace for $6 \mathrm{~h}$ and weighing of the resulting ash. The TS was calculated from the resulting masses after drying at $105^{\circ} \mathrm{C}$, and for VS the resulting masses of ash were used to determine the volatile solids as difference between the dried amount and the ash.

The loss of volatile organic compounds during the drying process was considered according to Eq. (1) [22].

$T S_{c}=T S_{n}+0.95 F A+0.08 L A+0.77 P D+1.00 O A$ 
In which $F A$ is the sum of fatty acids $\left(F A, \mathrm{C}_{2}-\mathrm{C}_{6}\right)$, LA is lactic acid (LA), PD is 1.2-propanediol, OA are alcohols $(\mathrm{OA})$ and $\mathrm{TS}_{\mathrm{n}}$ is the measured value of dry matter, all in $\mathrm{g}$ $\mathrm{kg}^{-1}$. The measured VS values were recalculated according to the corrected $\mathrm{TS}_{\mathrm{c}}$.

\section{Chemical Composition of the Substrate}

The chemical composition of the fresh cut grass was determined with Weender van Soest analysis at the Analytical Chemistry Unit of the Core Facility of the University of Hohenheim. The values are shown based on the TS content of the substrate. For simplification, in the entire results section, they are shown as $\mathrm{g} \mathrm{kg}^{-1}$. The content of crude ash (CA), crude protein (CP), crude fat (CL) and crude fibre (CF) were performed according to the regulation of the Commission of the European Communities 152/2009 III [23]. Whereas neutral detergent fibre (NDF), acid detergent fibre (ADF) and acid detergent lignin (ADL) where determined according to the standard of the VDLUFA [24].

\section{Determination of Volatile Fatty Acids with Capillary Gas Chromatography}

The determination of volatile fatty acids (VFA) of the liquid and solid samples was performed by gas chromatography (GC) (GC2010plus, Shimadzu Corp., Japan) with an autoinjector (AOC-20i, Shimadzu Corp., Japan), and FID Detector and a capillary column (WCOT Fused Silica, Varian Medical Systems Inc., US). The concentrations of acetic acid, propionic acid, $\mathrm{n}$ - and iso-valeric acid, $\mathrm{n}$ - and iso-butyric and caproic acid were measured, after calibration with an appropriate standard solution. The concentrations of VFAs are shown based on the total solids content of the sample. For simplification, in the entire results section, they are shown as $\mathrm{g} \mathrm{kg}^{-1}$.

\section{Determination of Lactic Acid, Ethanol and 1.2-Propanediol with High Performance Liquid Chromatography (HPLC)}

The determination of lactic acid, ethanol, 1.2-propanediol was done with HPLC (Bischoff Analysentechnik u. -ger. GmbH, Germany) after calibration with an appropriate standard. The HPLC is equipped with a RI-Detektor, an Aminex HPLC column (Aminex HPX-87 H, Bio-Rad, US) and a precolumn (HPX-87 H, Bio-Rad, US). The concentration of lactic acid, ethanol and 1.2-propanediol are, expressed based on the total solids content of the sample. For simplification, in the entire results section, these are only shown as $\mathrm{g} \mathrm{kg}^{-1}$.

\section{Chemical Oxygen Demand (COD)}

The determination of the chemical oxygen demand was performed using a cuvette test (LCK 014, Hach Lange $\mathrm{GmbH}$, Germany) with a measuring range between 1000 and $10,000 \mathrm{mg} / \mathrm{L} \mathrm{O}_{2}$. Because of the high COD load of the samples, they were diluted 1:10 with distilled water. After pipetting the samples into the cuvettes, the pulping process was carried out at $170{ }^{\circ} \mathrm{C}$ in a high temperature thermostat (HT200S, Hach Lange GmbH, Germany). Later the COD of the samples was measured with a photometer (DR 3900, Hach Lange GmbH, Germany).

\section{Measurement of the pH-Value}

For liquid samples, the $\mathrm{pH}$ value was determined at room temperature without stirring with a laboratory $\mathrm{pH}$ meter (pH meter 211, HANNA Instruments, USA) using a single-rod glass electrode. The electrode was previously calibrated with $\mathrm{pH} 7$ and $\mathrm{pH} 4$ calibration solutions. The temperature effect was compensated based on temperature measurement (HI7669/2 W, HANNA Instruments, USA). For solid samples, $10 \mathrm{~g}$ of the sample materials was mixed with $100 \mathrm{ml}$ distilled water and shaken for $1 \mathrm{~h}$ with an orbital shaker (KS-15, Edmund Br GmbH, Germany).

\section{Statistical Methods}

The data was tested for significant differences with the Kruskal-Wallis test. Subsequently an one-way ANOVA was done and the Tukey post hoc test was applied. Statistical analysis was done with the software R-Studio and the package agricolae $[25,-27]$. The figures were plotted with R-Studio and the package ggplot2 [26, 28].

\section{Results and Discussion}

\section{Raw Material Composition}

The grass used for fermentation had a TS content of $389 \mathrm{~g}$ $\mathrm{kg}^{-1}$ and a VS content of $355 \mathrm{~g} \mathrm{~kg}^{-1}$. Both are in the typical range for grass used for ensiling [29]. Likewise, the contents of crude ash (CA) $\left(88 \mathrm{~g} \mathrm{~kg}^{-1}\right)$, crude fibre (CF) $\left(255 \mathrm{~g} \mathrm{~kg}^{-1}\right)$, crude protein (CP) $\left(122 \mathrm{~g} \mathrm{~kg}^{-1}\right)$ and crude fat (CL) $\left(27 \mathrm{~g} \mathrm{~kg}^{-1}\right)$ (Table 2). In the case of the sum of structural substances, specified as neutral detergent fibre (NDF), a content of $526 \mathrm{~g} \mathrm{~kg}^{-1}$ was measured and the amount of lignin, defined as acid detergent lignin (ADL), 
Table 2 Raw material composition of the used grass for ensiling

\begin{tabular}{llll}
\hline Ingredient & This study & $\begin{array}{l}\text { LUFA Nord-West } \\
(2013-2020)^{2}\end{array}$ \\
\cline { 3 - 4 } & $\mathrm{g} \mathrm{kg}^{-1}$ & $\mathrm{~g} \mathrm{~kg}^{-1}$ & \\
\hline $\mathrm{CA}$ & 88 & 107 & \pm 4.3 \\
$\mathrm{CF}$ & 255 & 254 & \pm 5.7 \\
$\mathrm{CP}$ & 122 & 161 & \pm 7.9 \\
$\mathrm{CL}$ & 27 & $\mathrm{n} . \mathrm{a}$. & n.a. \\
$\mathrm{NDF}$ & 526 & 476 & \pm 12 \\
$\mathrm{ADF}$ & 279 & 289 & \pm 9.1 \\
$\mathrm{ADL}$ & 21 & 22 & n.a. \\
TS & 389 & 396 & \pm 19 \\
$\mathrm{VS}^{\mathrm{b}}$ & 355 & 354 & \pm 1.8 \\
\hline
\end{tabular}

a Based on fresh matter

${ }^{\mathrm{b}}$ Mean of yearly average value with standard deviation [30]

was $21 \mathrm{~g} \mathrm{~kg}^{-1}$. The fraction of acid detergent fibres (ADF) was measured at $279 \mathrm{~g} \mathrm{~kg}^{-1}$.

\section{Chemical composition of the silage}

The grass silage was stored according to the treatment at 22 $\pm 1^{\circ} \mathrm{C}$ or $37 \pm 1^{\circ} \mathrm{C}$ for $3,14,30$, and 90 days. Whereas Maillard reactions can occur in silages at temperatures between 35 and $40{ }^{\circ} \mathrm{C}[31,32]$. This can lead to energy losses during storage [33].

Table 3 shows the chemical composition, $\mathrm{pH}$ and VSloss of the substrate after ninety days of fermentation. For all treatments stored at $37{ }^{\circ} \mathrm{C}$, excluding treatment WB37, 1.2-propanediol formed during storage. Its concentration lies between 9.0 and $33.1 \mathrm{~g} \mathrm{~kg}^{-1}$. In the literature a degradation of lactic acid to acetic acid and 1.2-propanediol is reported, with an optimal temperature between 20 and $37{ }^{\circ} \mathrm{C}$, which could be the reason for the accumulation of 1.2-propanediol during fermentation at $37^{\circ} \mathrm{C}$ [36].

The development of $\mathrm{pH}$ and the concentrations of lactic acid, acetic acid, butyric acid and ethanol for all treatments are shown in Fig. 1. Considering the $\mathrm{pH}$ development of the control treatment (C20), it followed the typical course for ensiling, with a fast decrease of $\mathrm{pH}$ in the first three days to $\mathrm{pH} 4$ [34]. This $\mathrm{pH}$ decrease is mainly caused by lactic acid production during fermentation. For the treatment C20, a final lactic acid concentration of $114.9 \pm 9.6 \mathrm{~g} \mathrm{~kg}^{-1}$ was achieved. While, a content of $56 \mathrm{~g} \mathrm{~kg}^{-1}$ was reached in another study (Table 3) [29]. But the concentration of lactic acid can differ widely according to raw material composition, buffering capacity and the dominant lactic acid bacteria species [35]. Overall, the highest concentration of lactic acid was reached by treatment B20 with $158.0 \pm 22.2 \mathrm{~g}$ $\mathrm{kg}^{-1}$. With regard to the untreated control treatment stored at $37{ }^{\circ} \mathrm{C}(\mathrm{C} 37)$, the lactic acid concentration $(67.7 \pm 6.3 \mathrm{~g}$ $\mathrm{kg}^{-1}$ ) was $41 \%$ lower and the acetic acid concentration (49.2 $\pm 3.4 \mathrm{~g} \mathrm{~kg}^{-1}$ ) was $148 \%$ higher when stored at $20^{\circ} \mathrm{C}$. Likewise, for all other treatments stored at $37^{\circ} \mathrm{C}$, a higher acetic acid concentration was observed compared to the same treatment stored at $20{ }^{\circ} \mathrm{C}$. For silage storage temperatures at $40{ }^{\circ} \mathrm{C}$, it is reported that due to a higher $\mathrm{pH}$-values and a lower lactic to acetic acid ratio, a curtailed fermentation, increased proteolysis and secondary heterolactic fermentation takes place which are resulting in a reduced silage quality for animal feeding [31]. In terms of the ethanol concentration, the values differ widely between 4.2 and $20.9 \mathrm{~g}$ $\mathrm{kg}^{-1}$ DM. The treatment WB20 showed the highest ethanol content and the treatment $\mathrm{C} 37$ showed the lowest amount of ethanol in the silage.

The highest VS-loss during fermentation and storage was measured for the treatments B20 (20.3\%) and B37 (20.5\%). Both are higher than the control treatments $(12.5 \% ; 13.1 \%)$. One reason for the high VS-losses could be the high generation and formation of organic acids, especially lactic acid and according to that the formation of $\mathrm{CO}_{2}$ through fermentation.

In the case of butyric acid concentration, only the treatments with a combination of low TS content and an increased buffering capacity formed the butyric acid during fermentation. Considering the fermentation durations, the formation of butyric acid began between days 3 and 14, but most of it was formed between days 30 and 90 . The generation of butyric acid went hand in hand with a significantly higher VS-loss $(18.7 \%, 18.9 \%)$ compared to the untreated control (12.5\%) and an increase in $\mathrm{pH}$ between days 30 and 90 . This might be caused by the higher $\mathrm{pK}_{\mathrm{a}}$-value of butyric acid and degradation of lactic acid. The highest butyric acid concentration was achieved by treatment WB37 with $40.5 \mathrm{~g}$ $\mathrm{kg}^{-1}$ at a theoretical initial TS content of $0.222 \mathrm{~g} \mathrm{~kg}^{-1}$. McEniry et al. [37] achieved a concentration of $20.6 \mathrm{~g} \mathrm{~kg}^{-1}$ by the addition of $10 \mathrm{~g} \mathrm{~kg}^{-1}$ carbonated lime and an initial DM content of $265 \mathrm{~g} \mathrm{~kg}^{-1}$. In another study, no butyric acid was detected with an addition of 8.6 and $17.2 \mathrm{~g} \mathrm{~kg}^{-1}$ and an initial TS content of $374 \mathrm{~g} \mathrm{~kg}^{-1}$ [29].

\section{Separation, Methane Yield Potential and Chemical Composition of the Press Juice}

\section{Separation}

The silage was separated after ninety days of fermentation. Figure 2 shows the mass share and losses of the resulting press cake, press juice, and losses due to the separation process. As expected, all treatments with a reduced TS content show a higher share of press juice from 37 to $43 \%$ compared to the treatments with higher TS with $15 \%-24 \%$. In case of the resulting press cake it is the other way around with 73\%-82\% (C20, B20, C37, B37) and 55\%-61\% (W20, 
동
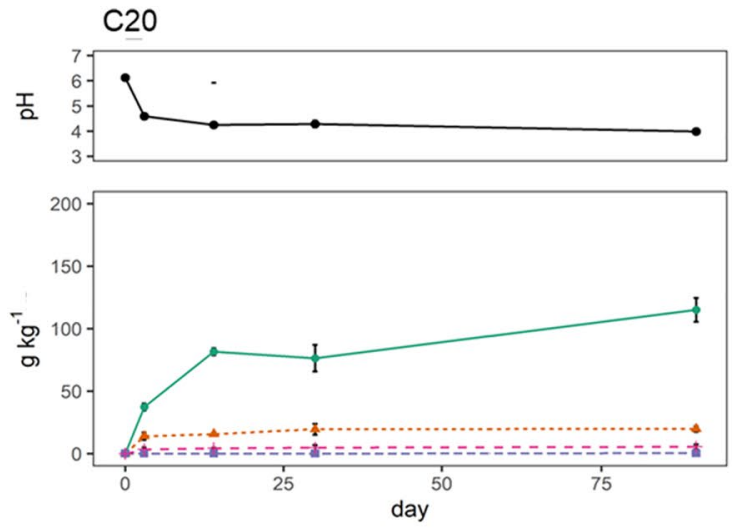

W20

등
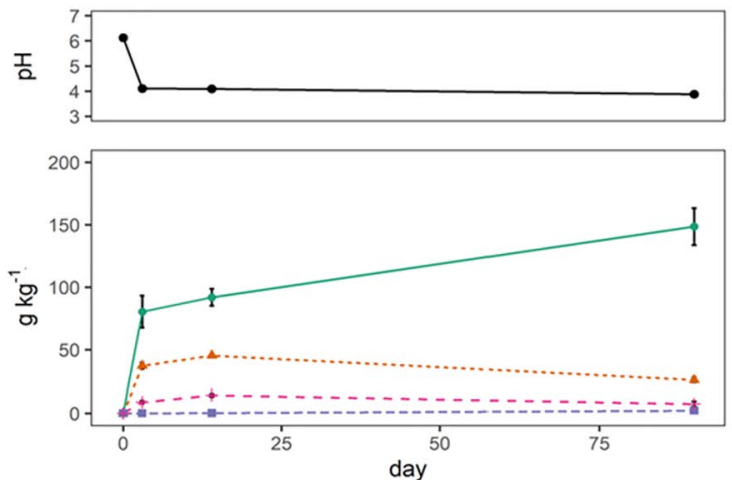

B20

동
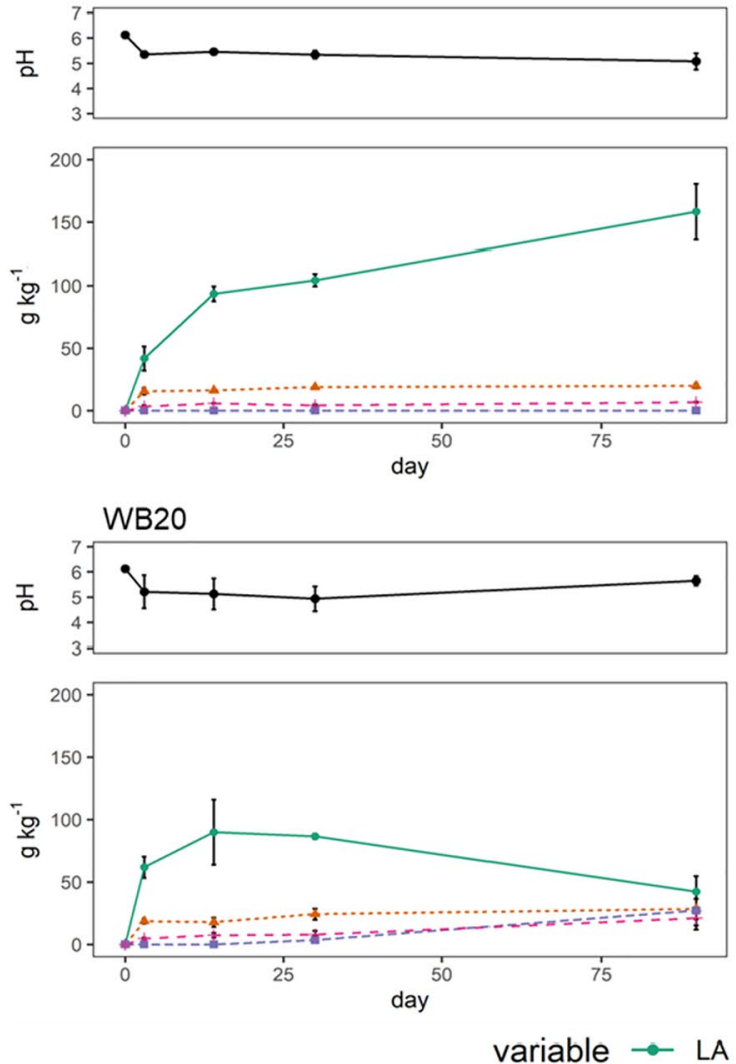

C37
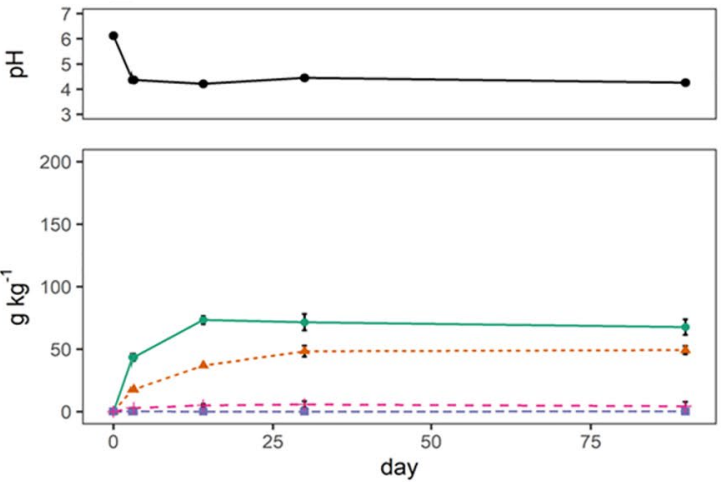

W37
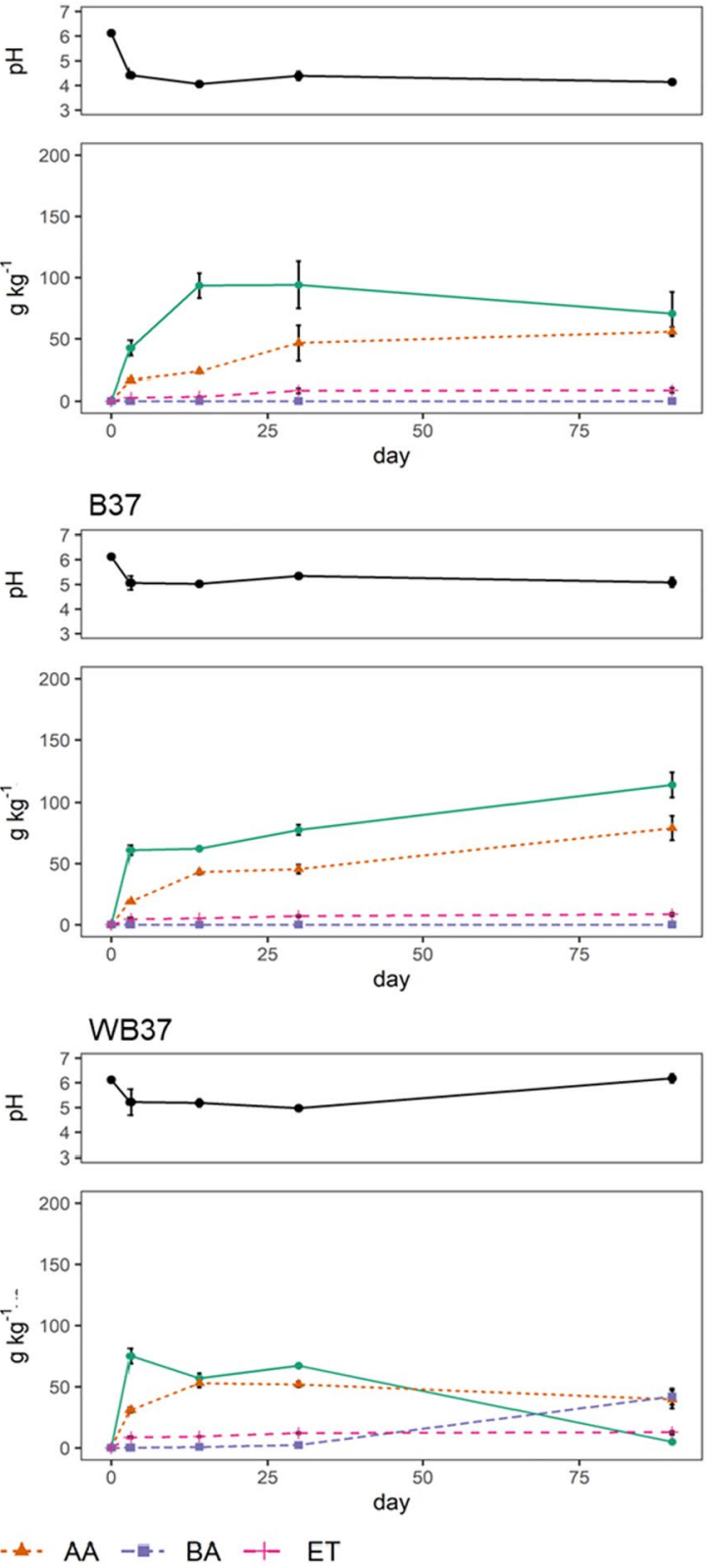

Fig. 1 Development of $\mathrm{pH}$, lactic acid (LA), acetic acid (AA), butyric acid (BA) and ethanol (ET) during fermentation shown as $\mathrm{g} \mathrm{kg}^{-1}$ total solids 
Table 3 Chemical composition, $\mathrm{pH}$ and VS-losses of the resulting silage after 90 days of fermentation

\begin{tabular}{|c|c|c|c|c|c|c|c|c|c|c|}
\hline Treatment & $\begin{array}{l}\mathrm{LA} \\
\mathrm{g} \mathrm{kg}^{-1}\end{array}$ & $\begin{array}{l}\mathrm{AA} \\
\mathrm{g} \mathrm{kg}^{-1}\end{array}$ & $\begin{array}{l}\mathrm{PA} \\
\mathrm{g} \mathrm{kg}^{-1}\end{array}$ & $\begin{array}{l}\text { iso-BA } \\
\mathrm{g} \mathrm{kg}^{-1}\end{array}$ & $\begin{array}{l}\mathrm{n}-\mathrm{BA} \\
\mathrm{g} \mathrm{kg}^{-1}\end{array}$ & $\begin{array}{l}\mathrm{BA} \\
\mathrm{g} \mathrm{kg}^{-1}\end{array}$ & $\begin{array}{l}\text { ET } \\
\mathrm{g} \mathrm{kg}^{-1}\end{array}$ & $\begin{array}{l}1.2 \mathrm{PD} \\
\mathrm{g} \mathrm{kg}^{-1}\end{array}$ & $\begin{array}{l}\text { VS-Loss } \\
\%\end{array}$ & $\begin{array}{l}\mathrm{pH} \\
-\log _{10} \alpha\left(\mathrm{H}^{+}\right)\end{array}$ \\
\hline $\mathrm{C} 20$ & $114.9^{\mathrm{b}} \pm 9.6$ & $19.8^{\mathrm{e}} \pm 2.3$ & $3.2^{\mathrm{b}} \pm 0.2$ & $<0.1$ & $0.4^{\mathrm{b}} \pm 0.3$ & $0.4^{\mathrm{c}} \pm 0.3$ & $5.4^{\mathrm{c}} \pm 2.0$ & $<0.1$ & $12.5^{\mathrm{a}} \pm 2.2$ & $4.0^{\mathrm{d}} \pm 0.0$ \\
\hline $\mathrm{C} 37$ & $67.7^{\mathrm{c}} \pm 6.3$ & $49.2^{\mathrm{bc}} \pm 3.4$ & $2.6^{\mathrm{b}} \pm 0.5$ & $<0.1$ & $0.2^{\mathrm{b}} \pm 0.2$ & $0.2^{\mathrm{c}} \pm 0.2$ & $4.2^{\mathrm{c}} \pm 3.6$ & $33.1^{\mathrm{a}} \pm 7.0$ & $13.1^{\mathrm{a}} \pm 5.2$ & $4.3^{\mathrm{d}} \pm 0.1$ \\
\hline W20 & $148.5^{\mathrm{ab}} \pm 14.8$ & $25.8^{\mathrm{de}} \pm 2.0$ & $3.4^{\mathrm{b}} \pm 1.2$ & $<0.1$ & $2.2^{\mathrm{b}} \pm 2.0$ & $2.2^{c} \pm 2.0$ & $7.5^{\mathrm{bc}} \pm 2.1$ & $<0.1$ & $11.8^{\mathrm{a}} \pm 3.4$ & $3.9^{\mathrm{d}} \pm 0.0$ \\
\hline W37 & $70.5^{\mathrm{c}} \pm 17.7$ & $55.7^{\mathrm{b}} \pm 3.7$ & $4.9^{\mathrm{b}} \pm 0.7$ & $<0.1$ & $<0.1$ & $<0.1$ & $8.9^{\mathrm{bc}} \pm 2.0$ & $9.0^{\mathrm{bc}} \pm 3.4$ & $17.2^{\mathrm{a}} \pm 6.9$ & $4.1^{\mathrm{d}} \pm 0.0$ \\
\hline B20 & $158.2^{\mathrm{a}} \pm 22.2$ & $19.7^{\mathrm{e}} \pm 1.9$ & $2.1^{\mathrm{b}} \pm 0.2$ & $<0.1$ & $<0.1$ & $<0.1$ & $6.7^{\mathrm{bc}} \pm 0.4$ & $<0.1$ & $20.3^{\mathrm{a}} \pm 4.4$ & $5.1^{\mathrm{c}} \pm 0.3$ \\
\hline B37 & $114.2^{\mathrm{b}} \pm 10.2$ & $78.9^{\mathrm{a}} \pm 10.0$ & $4.7^{\mathrm{b}} \pm 1.5$ & $<0.1$ & $<0.1$ & $<0.1$ & $8.4^{\mathrm{bc}} \pm 1.2$ & $21.1^{\mathrm{ab}} \pm 11.5$ & $20.5^{\mathrm{a}} \pm 9.1$ & $5.1^{\mathrm{c}} \pm 0.2$ \\
\hline WB20 & $42.3^{\mathrm{cd}} \pm 12.4$ & $28.5^{\mathrm{de}} \pm 8.1$ & $4.5^{\mathrm{b}} \pm 0.8$ & $0.3^{\mathrm{b}} \pm 0.4$ & $26.8^{\mathrm{a}} \pm 14.7$ & $27.1^{\mathrm{b}} \pm 15.1$ & $20.9^{\mathrm{a}} \pm 5.7$ & $<0.1$ & $18.7^{\mathrm{a}} \pm 3.8$ & $5.7^{\mathrm{b}} \pm 0.2$ \\
\hline WB37 & $5.1^{\mathrm{d}} \pm 5.6$ & $39.6^{\mathrm{cd}} \pm 7.4$ & $9.9^{\mathrm{a}} \pm 1.6$ & $1.5^{\mathrm{a}} \pm 0.4$ & $40.5^{\mathrm{a}} \pm 6.2$ & $42.0^{\mathrm{a}} \pm 6.6$ & $12.9^{\mathrm{b}} \pm 0.9$ & $<0.1$ & $18.9^{\mathrm{a}} \pm 2.8$ & $6.2^{\mathrm{a}} \pm 0.2$ \\
\hline
\end{tabular}

$L A$ lactic acid, $A A$ acetic acid, $P A$ propionic acid, $B A$ sum of iso- and n-butyric acid, $E T$ ethanol, 1.2PD 1.2-propanediol, VS-Loss loss of volatile solids, $C 20$ untreated control stored at $20{ }^{\circ} \mathrm{C}, C 37$ untreated control stored at $37{ }^{\circ} \mathrm{C}, W 20$ treatment with water addition, $W 37$ treatment with water addition, $B 20$ treatment with $\mathrm{CaCO}_{3}$ addition, $B 37$ treatment with $\mathrm{CaCO}_{3}$ addition, $W B 20$ combination of water and $\mathrm{CaCO}_{3}$, WB37 combination of water and $\mathrm{CaCO}_{3}$

Volatile fatty acid concentrations are shown as $\mathrm{g} \mathrm{kg}^{-1}$ total solids. Different letters indicate significant differences between the treatments at $\mathrm{p}<$ 0.05

WB20, W27, WB37). All together the losses lie between 1.5 and $3.8 \%$. In general, a higher press juice (PJ) yield is preferred to increase the amount of extracted organic acids.

\section{Methane Yield Potential}

After the separation procedure, the methane yield potential of the original silage and the produced press cake (PC) was determined. The resulting methane yield potential for the PC of the control treatment (C20) was $0.353 \pm 0.002 \mathrm{~m}^{2} \mathrm{~kg}^{-1}$, which is comparable to other studies for grass silage e.g. $0.344-0.383 \mathrm{~m}^{2} \mathrm{~kg}^{-1}$ [37] (Fig. 3). For the untreated control (C37), a specific methane yield of $0.371 \pm 0.018 \mathrm{~m}^{2} \mathrm{~kg}^{-1}$ was achieved, but there was no significant difference to the other control treatment stored at room temperature. Altogether the lowest yield was achieved for the treatment B20 with $0.317 \pm 0.024 \mathrm{~m}^{2} \mathrm{~kg}^{-1}$, which is significantly lower than the treatments C37, W20, B37, and WB37. But, an effect of silage fermentation temperature on the specific methane yield could not be proved. It is reported that the ensiling fermentation characteristics have only a minor effect on the SMY. But high butyric acid and ethanol concentrations can lead to higher SMY's. Nevertheless, due to high VS and energy losses through butyric acid fermentation, the higher SMY's cannot compensate these losses [37].

When comparing the specific methane yield to the original silage before separation, significant differences were measured between press cake and silage of the treatments W20, W37 and B37 (Fig. 3). All other treatments did not show a significant difference in SMY before and after separation. But through the separation process, there was a considerable loss of mass and especially organic acids, which are dissolved in the produced press juice.

\section{Chemical Composition of the Press Juice}

Considering the number of organics in the press juice, expressed in the form of the COD value, it ranged from 115.4 to $186.5 \mathrm{~g} \mathrm{~kg}^{-1}$. There were two groups, which were significantly different from each other. All treatments with reduced TS content showed lower values (115.4-123.7 $\mathrm{g} \mathrm{kg}^{-1}$ ) than the treatments without the addition of water $\left(164.1-186.4 \mathrm{~g} \mathrm{~kg}^{-1}\right)$. For the concentration of lactic acid, the highest value was $68.9 \mathrm{~g} \mathrm{~kg}^{-1}$ for the treatment $\mathrm{C} 20$ and the lowest value was measured for treatment WB37 with $2.4 \mathrm{~g} \mathrm{~kg}^{-1}$. Similarly, for day 90 , as it was expected, only two treatments WB20 $\left(10.7 \mathrm{~g} \mathrm{~kg}^{-1}\right)$ and WB37 (20.1 $\mathrm{g} \mathrm{kg}^{-1}$ ) showed considerable amounts of butyric acid. Compared to other studies and addition of microorganisms for butyric acid production, and the use of glucose as substrate, butyric acid concentrations from 6.3 to $62.8 \mathrm{~g} \mathrm{~L}^{-1}$ were achieved [38]. For agricultural raw materials like corn stalk and the addition of $C$. thermobutyricum, $15.82 \mathrm{~g} \mathrm{~L}^{-1}$ butyric acid concentration was achieved [13]. Furthermore, from hydrolysed wheat straw, 19-20 $\mathrm{g} \mathrm{L}^{-1}$ are reported [14]. The resulting concentration of butyric acid in the separated fermentation broth in this study is comparable to other agricultural raw materials and processes. On one hand, the whole fermentation process is simpler, because the addition of special microorganisms and a pre-treatment of the substrate is not required. On the other hand, the resulting fermentation contains many impurities like other organic acids and suspended solids. Additionally, the recovery of the butyric acid from the produced press juice is challenging, like for other organic acids [39]. But to make the whole fermentation more controllable and repeatable, a pre-treatment of the raw material to get a homogeneous 
substrate and the selective addition of Clostridia should be considered for future experiments. When calculating the butyric acid yield $\left(\mathrm{Y}_{\mathrm{BA}}\right)$, based on the used amount of VS for ensiling and the butyric acid concentration in the press juice, a yield of $9.2\left(\mathrm{~g} \mathrm{~kg}^{-1}\right)$ and $33.1\left(\mathrm{~g} \mathrm{~kg}^{-1}\right)$ was achieved. However, only $3.3 \%$ of the used VS was converted to butyric acid, so there is need for further improvement of the process to achieve a higher butyric acid yield (Table 4).

\section{Upscaling, Production Scheme and Technical Obstacles}

Following the production scheme of a Green Biorefinery assuming a grass yield per ha and year of $10 \mathrm{Mg}_{\mathrm{VS}}$, and using the corresponding TS-losses during fermentation and separation, two treatments with the highest yield in butyric acid per VS (WB20, WB37) were selected (Fig. 4). In both cases, the total amount of organic acids in the silage was lower in comparison to the corresponding control treatment. But the amount of organic acids separated from the

Table 4 Chemical composition, COD, $\mathrm{pH}$ and specific butyric acid yield of the produced press juice after 90 days of fermentation

\begin{tabular}{|c|c|c|c|c|c|c|c|c|c|}
\hline Treatment & $\begin{array}{l}\mathrm{LA} \\
\mathrm{g} \mathrm{kg}^{-1} \\
\end{array}$ & $\begin{array}{l}\mathrm{AA} \\
\mathrm{g} \mathrm{kg}^{-1} \\
\end{array}$ & $\begin{array}{l}\mathrm{PA} \\
\mathrm{g} \mathrm{kg}^{-1} \\
\end{array}$ & $\begin{array}{l}\mathrm{BA} \\
\mathrm{g} \mathrm{kg}^{-1} \\
\end{array}$ & $\begin{array}{l}\text { ET } \\
\mathrm{g} \mathrm{kg}^{-1} \\
\end{array}$ & $\begin{array}{l}1.2 \mathrm{PD} \\
\mathrm{g} \mathrm{kg}^{-1} \\
\end{array}$ & $\begin{array}{l}\mathrm{COD} \\
\mathrm{g} \mathrm{kg}^{-1} \\
\end{array}$ & $\begin{array}{l}\mathrm{pH} \\
-\log _{10} \alpha\left(\mathrm{H}^{+}\right)\end{array}$ & $\begin{array}{l}\mathrm{Y}_{\mathrm{BA}} \\
\mathrm{g} \mathrm{kg}^{-1}\end{array}$ \\
\hline $\mathrm{C} 20$ & $68.9^{\mathrm{a}} \pm 2.3$ & $12.7^{\mathrm{cd}} \pm 0.3$ & $0.9^{\mathrm{cd}} \pm 0.1$ & $0.2^{\mathrm{c}} \pm 0.1$ & $4.2^{\mathrm{ab}} \pm 0.5$ & $<0.1$ & $186.5^{\mathrm{a}} \pm 4.3$ & $4.0^{\mathrm{d}} \pm 0.0$ & n.a \\
\hline C37 & $40.0^{\mathrm{b}} \pm 1.1$ & $30.9^{\mathrm{ab}} \pm 3.2$ & $0.9^{\mathrm{cd}} \pm 0.1$ & $0.6^{c} \pm 0.2$ & $2.9^{\mathrm{b}} \pm 2.5$ & $18.6^{\mathrm{a}} \pm 5.8$ & $171.2^{\mathrm{a}} \pm 0.3$ & $4.2^{\mathrm{cd}} \pm 0.1$ & n.a \\
\hline W20 & $56.2^{\mathrm{a}} \pm 5.6$ & $9.8^{\mathrm{d}} \pm 1.2$ & $0.6^{\mathrm{d}} \pm 0.0$ & $0.7^{\mathfrak{c}} \pm 0.8$ & $3.3^{b} \pm 0.5$ & $<0.1$ & $123.7^{\mathrm{b}} \pm 22.2$ & $3.9^{\mathrm{d}} \pm 0.0$ & n.a \\
\hline W37 & $30.4^{b c} \pm 10.2$ & $23.0^{\mathrm{bc}} \pm 4.8$ & $1.8^{\mathrm{bc}} \pm 0.4$ & $<0.1$ & $4.3^{\mathrm{ab}} \pm 0.1$ & $6.3^{\mathrm{bc}} \pm 1.6$ & $122.0^{\mathrm{b}} \pm 15.0$ & $4.1^{\mathrm{d}} \pm 0.1$ & n.a \\
\hline B20 & $55.8^{\mathrm{a}} \pm 0.6$ & $12.8^{\mathrm{cd}} \pm 0.1$ & $0.7^{\mathrm{d}} \pm 0.1$ & $<0.1$ & $4.5^{\mathrm{ab}} \pm 0.2$ & $<0.1$ & $164.1^{\mathrm{a}} \pm 1.6$ & $4.5^{\mathrm{c}} \pm 0.1$ & n.a \\
\hline B37 & $41.1^{\mathrm{b}} \pm 4.0$ & $37.7^{\mathrm{a}} \pm 7.0$ & $2.4^{\mathrm{b}} \pm 0.6$ & $0.2^{\mathrm{c}} \pm 0.1$ & $4.8^{\mathrm{ab}} \pm 1.0$ & $12.5^{\mathrm{ab}} \pm 4.4$ & $175.7^{\mathrm{a}} \pm 18.0$ & $4.9^{\mathrm{b}} \pm 0.2$ & n.a \\
\hline WB20 & $19.9^{c} \pm 2.1$ & $12.2^{\mathrm{cd}} \pm 3.2$ & $1.4^{\mathrm{cd}} \pm 0.5$ & $10.7^{\mathrm{b}} \pm 6.0$ & $8.9^{\mathrm{a}} \pm 3.4$ & $<0.1$ & $117.6^{b} \pm 0.3$ & $5.3^{\mathrm{ab}} \pm 0.0$ & 9.2 \\
\hline WB37 & $2.4^{\mathrm{d}} \pm 3.0$ & $16.9^{\mathrm{cd}} \pm 0.4$ & $4.5^{\mathrm{a}} \pm 0.2$ & $20.1^{\mathrm{a}} \pm 4.5$ & $3.9^{\mathrm{b}} \pm 0.7$ & $1.7^{\mathrm{c}} \pm 0.1$ & $115.4^{\mathrm{b}} \pm 2.8$ & $5.7^{\mathrm{a}} \pm 0.3$ & 33.1 \\
\hline
\end{tabular}

All concentrations are given as $\mathrm{g} \mathrm{kg}^{-1}$ fresh matter, whereas the butyric acid yield is given as $\mathrm{g} \mathrm{kg}^{-1}$ volatile solids at the beginning of the experiment. Different letters indicate significant differences between the treatments for $\mathrm{p}<0.05$

$L A$ lactic acid, $A A$ acetic acid, $P A$ propionic acid, $B A$ sum of iso- and n-butyric acid, ET ethanol, 1.2PD 1.2-propanediol, $Y_{\mathrm{BA}}$ Butyric acid yield per kg VS of fresh grass, $C 20$ untreated control stored at $20^{\circ} \mathrm{C}, C 37$ untreated control stored at $37^{\circ} \mathrm{C}$, $W 20$ treatment with water addition, W37 treatment with water addition, $B 20$ treatment with $\mathrm{CaCO}_{3}$ addition, $B 37$ treatment with $\mathrm{CaCO}_{3}$ addition, WB2O combination of water and $\mathrm{CaCO}_{3}, W B 37$ combination of water and $\mathrm{CaCO}_{3}$

Fig. 2 Results of fractionation through the tincture press. Different letters $\left({ }^{\mathrm{a}, \mathrm{b}, \mathrm{c}}\right)$ indicate significant differences between the treatment within the fraction (press cake (PC), press juice (PJ), Loss) at $\mathrm{p}<0.05$
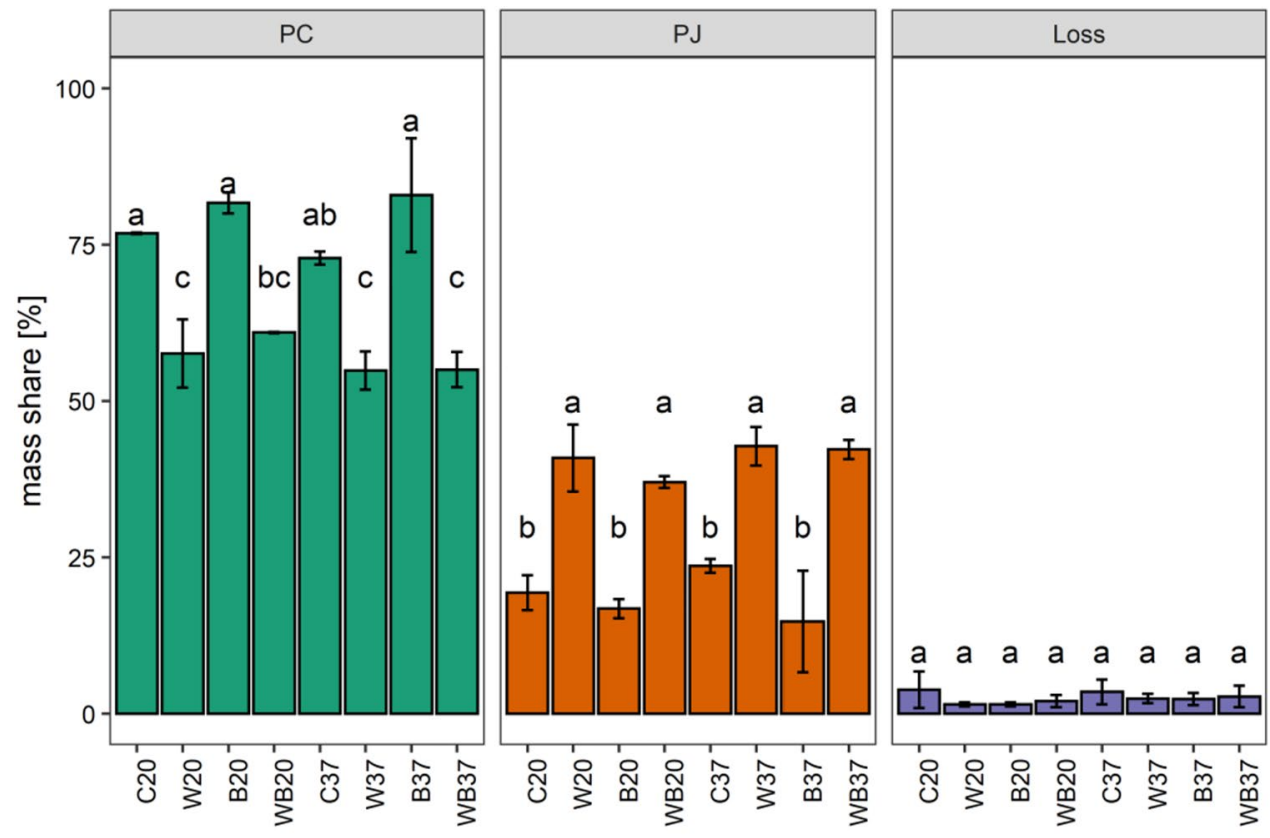

variable

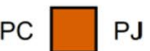

Loss 

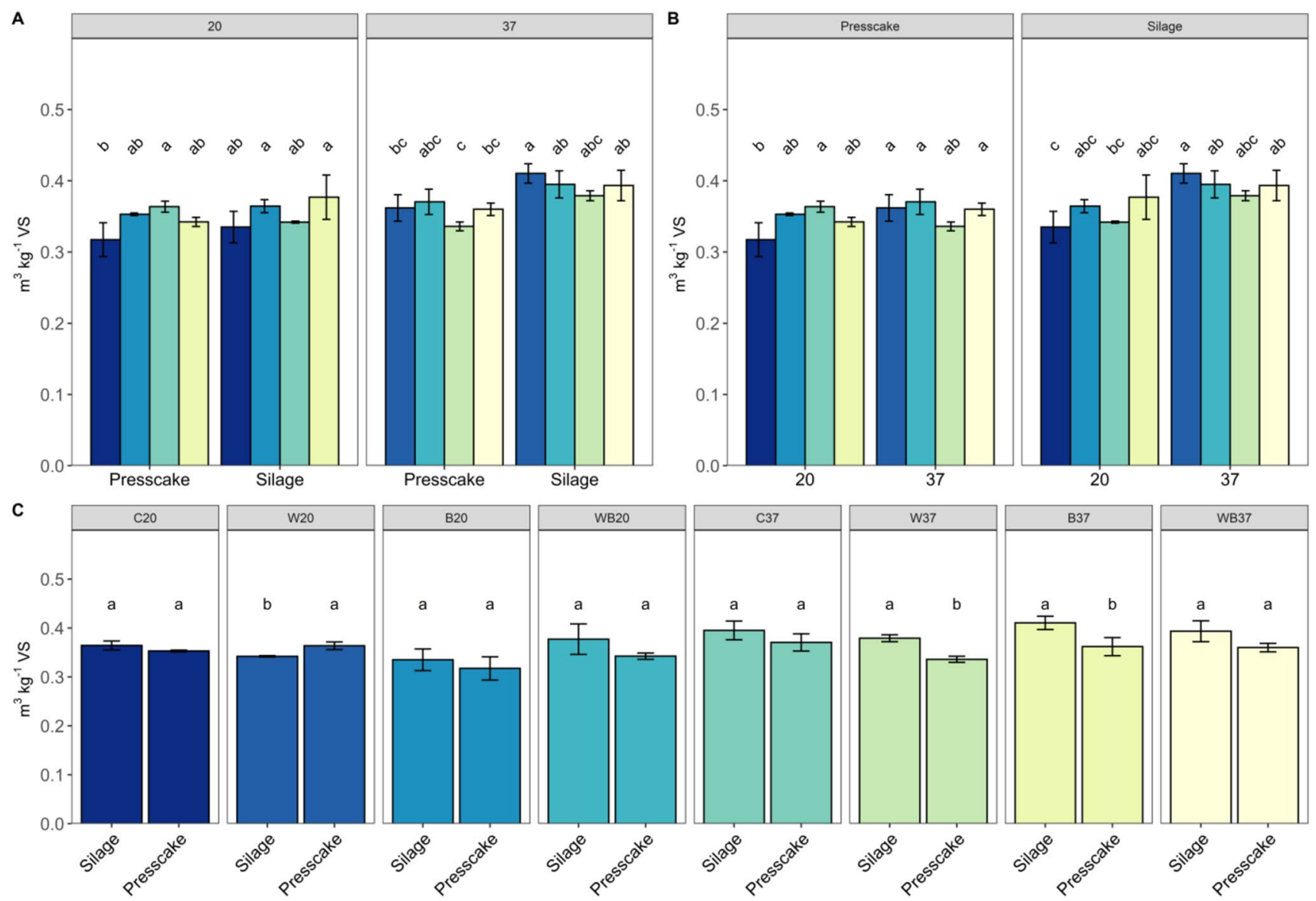

variation

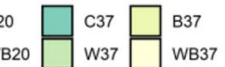

Fig. 3 Specific methane yields of the investigated treatments with comparison between silage and press cake within the respective temperatures $(\mathbf{A})$, within the fraction $(\mathbf{B})$, and comparison between the different fractions of the same treatment $(\mathbf{C})$. Different letters indicate significant differences between the treatments at the same temperature (A), between the treatments at the same fraction $(\mathbf{B})$ and between the fraction at the same treatment $(\mathbf{C})$ at $\mathrm{p}<0.05$
Fig. 4 Potential yield per hectare and year for ethanol (ET), n-butyric acid (n.BA), acetic acid (AA) and lactic acid (LA) of the control treatments stored at 20 and $37^{\circ} \mathrm{C}(\mathrm{C} 20, \mathrm{C} 37)$ and corresponding treatments with reduced $\mathrm{TS}$ and $\mathrm{CaCO}_{3}$ addition (WB20, WB37)
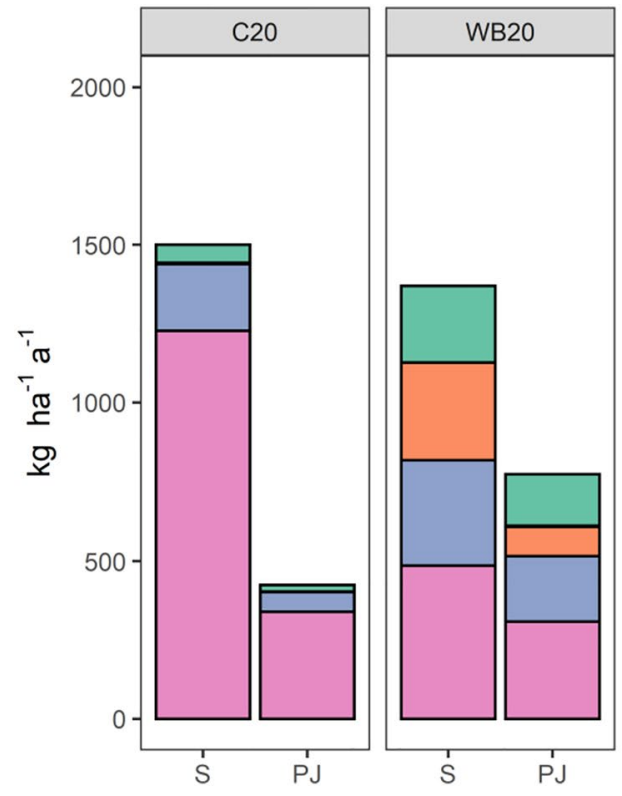

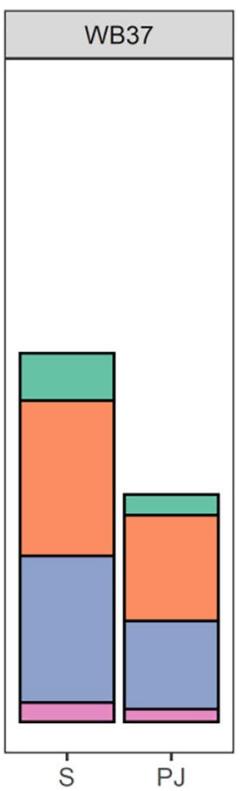

Variable

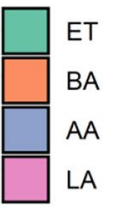


produced silage was higher in the treated silages, which is a result of the reduced TS content of the silage. Altogether an amount of $652 \mathrm{~kg} \mathrm{ha}^{-1} \mathrm{a}^{-1}$ of organic acids was produced for treatment WB37, which was $64 \%$ of the organic acids in the original silage. Considering the butyric acid yield, this treatment produced the highest amount per ha with $332 \mathrm{~kg}$ $\mathrm{ha}^{-1} \mathrm{a}^{-1}$. The treatment WB20 also had high butyric acid concentrations in the press juice, but the amount produced per ha $\left(93 \mathrm{~kg} \mathrm{ha}^{-1} \mathrm{a}^{-1}\right)$ was considerably lower. The theoretical amount of butyric acid, which can be produced in this production scheme could contribute to the value-added chain of anaerobic digestion of agricultural substrates. However, to make the butyric acid available, further processing of the produced press juice is necessary to gain a product which can be used by the industry. One possible method could be a first filtration step by ceramic membranes to remove suspended particles, followed by a liquid-liquid extraction and distillation. Nonetheless, the main disadvantages are the cost, solvent's toxicity and high energy consumption of the distillation [13]. A precipitation crystallization, also called as salting-out method is reported to be promising for the purification of fermentation broths and to separate butyric acid. But further research is necessary for the optimization and upscaling $[13,40]$.

In the case of methane production, for the resulting press cake of the treatment $20 \mathrm{WB}$, an amount of $2567 \mathrm{~m}_{\mathrm{CH} 4}^{3} \mathrm{ha}^{-1}$ $\mathrm{a}^{-1}$ could be produced. This is a loss of $20 \%$ compared to the silage methane yield per ha of the control treatment $\mathrm{C} 20$ $\left(3,193 \mathrm{~m}^{3} \mathrm{ha}^{-1} \mathrm{a}^{-1}\right)$. Regarding the press cake of the treatment WB37 $\left(2778 \mathrm{~m}^{3} \mathrm{ha}^{-1} \mathrm{a}^{-1}\right)$, a loss of $19 \%$ was observed compared to the unseparated silage of the untreated control (C37) $\left(3429 \mathrm{~m}^{3} \mathrm{ha}^{-1} \mathrm{a}^{-1}\right)$. The overall production scheme with its methane and organic acid yields is highly dependent on the quality of the used raw material and thereby on the environmental as well as the weather conditions in the harvesting year and the cultivation conditions.

\section{Conclusions}

The ensiling process is basically a lactic acid fermentation, but when the ensiling conditions are changed, butyric acid can also be produced. Consequently, this process is also accompanied with higher TS losses during storage. When considering the final butyric acid concentration in the fermentation broth, this method can compete with other butyric acid production processes that use agricultural raw materials. It is simpler because pre-treating of the substrate is not necessary and it could be integrated into a farm with an anaerobic digestion plant, where synergy effects could be achieved. The main disadvantage of the whole process is the purification and extraction of the produced butyric acid, to make it available for the chemical industry and further utilization. However, further research is necessary to improve this process in the case of optimal TS and VS content and buffer addition for butyric acid production including the raw material composition and quality. Furthermore, the addition of selected butyric acid producing bacteria, microbial analysis and a pre-treatment step for hydrolysis of the biomass should be considered.

Acknowledgements The work was funded by the Federal Ministry of Food and Agriculture (BMEL) within the scope of the project "OptigärDevelopment of efficient two-phase biogas plants via a coupled energetic and material use after separation of hydrolysis products" (FKZ 224-005-15). The authors acknowledge the support from our project partners Rainer Bolduan (European Institute for Energy Research), Sarah Bger, Sebastian Reinhardt, Wolfgang Becker (all Fraunhofer Institute for Chemical Technology) and Ralph Leistner (Lipp GmbH). Many thanks go to our colleagues Benedikt Hmann for his dedicated work on the Hohenheim Biogas Yield test, Padma Priya Ravi for the proofreading and English language correction, and Annette Buschmann and Jacqueline Kindermann for analysing the samples and their precise work in the analytical laboratory. Furthermore, the authors would like to thank the student assistants Celina Spangenberger and Nathalie Brucker for their help carrying out the experiments.

Funding Open Access funding enabled and organized by Projekt DEAL. The work was funded by the Federal Ministry of Food and Agriculture (BMEL) of Germany within the scope of the project "Optigär- Development of efficient two-phase biogas plants via a coupled energetic and material use after separation of hydrolysis products" (FKZ 224-005-15).

Availability of Data and Material The collected data can be handed out upon request.

Code Availability (Software Application or Custom Ccode) The program code for data analysis in R is not supplied. On the basis of the data, an evaluation can be carried out with the help of the functions mentioned in the method section.

\section{Declarations}

Conflict of interest The manuscript is the original work of the authors and was not previously submitted to Waste and Biomass Valorization. All authors declare no conflicts of interest.

Open Access This article is licensed under a Creative Commons Attribution 4.0 International License, which permits use, sharing, adaptation, distribution and reproduction in any medium or format, as long as you give appropriate credit to the original author(s) and the source, provide a link to the Creative Commons licence, and indicate if changes were made. The images or other third party material in this article are included in the article's Creative Commons licence, unless indicated otherwise in a credit line to the material. If material is not included in the article's Creative Commons licence and your intended use is not permitted by statutory regulation or exceeds the permitted use, you will need to obtain permission directly from the copyright holder. To view a copy of this licence, visit http://creativecommons.org/licenses/by/4.0/. 


\section{References}

1. Faostat: Land use. http://www.fao.org/faostat/en/\#data/RL (2017). Accessed 26 July 2020

2. Agler, M.T., Wrenn, B.A., Zinder, S.H., Angenent, L.T.: Waste to bioproduct conversion with undefined mixed cultures: the carboxylate platform. Trends Biotechnol. (2011). https://doi.org/10. 1016/j.tibtech.2010.11.006

3. Lemmer, A., Krl, J.: Demand-driven biogas production in anaerobic filters. Appl. Energy (2017). https://doi.org/10.1016/j.apene rgy.2016.10.073

4. Hahn, H., Krautkremer, B., Hartmann, K., Wachendorf, M.: Review of concepts for a demand-driven biogas supply for flexible power generation. Renew. Sustain. Energy Rev. (2014). https://doi. org/10.1016/j.rser.2013.08.085

5. Mauky, E., Jacobi, H.F., Liebetrau, J., Nelles, M.: Flexible biogas production for demand-driven energy supply-feeding strategies and types of substrates. Bioresour. Technol. (2015). https://doi.org/10.1016/j.biortech.2014.08.123

6. Kamm, B., Schke, P., Hille, C.: Green biorefinery - industrial implementation. Food Chem. (2016). https://doi.org/10.1016/j. foodchem.2015.11.088

7. Kamm, B., Kamm, M.: Principles of biorefineries. Appl. Microbiol. Biotechnol. (2004). https://doi.org/10.1007/ s00253-003-1537-7

8. Thang, V.H., Koschuh, W., Kulbe, K.D., Kromus, S., Krotscheck, C., Novalin, S.: Desalination of high salt content mixture by two-stage electrodialysis as the first step of separating valuable substances from grass silage. Desalination (2004). https:// doi.org/10.1016/S0011-9164(04)00068-2

9. Santamaría-Fernández, M., Molinuevo-Salces, B., Kiel, P., Steenfeldt, S., Uellendahl, H., Lk, M.: Lactic acid fermentation for refining proteins from green crops and obtaining a high quality feed product for monogastric animals. J. Clean. Prod. (2017). https://doi.org/10.1016/j.jclepro.2017.06.115

10. Franco, M., Hurme, T., Winquist, E., Rinne, M.: Grass silage for biorefinery-a meta-analysis of silage factors affecting liquid-solid separation. Grass Forage Sci. (2019). https://doi.org/ $10.1111 /$ gfs. 12421

11. Steinbrenner, J., Nägele, H.-J., Buschmann, A., Hmann, B., Oechsner, H.: Testing different ensiling parameters to increase butyric acid concentration for maize silage, followed by silage separation and methane yield potential of separated solids residues. Bioresour. Technol. Rep. (2019). https://doi.org/10.1016/j. biteb.2019.100193

12. Dwidar, M., Park, J.-Y., Mitchell, R.J., Sang, B.-I.: The future of butyric acid in industry. Sci. World J. (2012). https://doi.org/ 10.1100/2012/471417

13. Jha, A.K., Li, J., Yuan, Y., Baral, N., Ai, B., Ai, B.: A review on bio-butyric acid production and its optimization. Int. J. Agric. Biol. 16, 1019 (2014)

14. Baroi, G.N., Baumann, I., Westermann, P., Gavala, H.N.: Butyric acid fermentation from pretreated and hydrolysed wheat straw by an adapted Clostridium tyrobutyricum strain. Microb. Biotechnol. (2015). https://doi.org/10.1111/1751-7915.12304

15. Fu, H., Le Yu, Lin, M., Wang, J., Xiu, Z., Yang, S.-T.: Metabolic engineering of Clostridium tyrobutyricum for enhanced butyric acid production from glucose and xylose. Metab. Eng. (2017). https://doi.org/10.1016/j.ymben.2016.12.014

16. Luo, H., Yang, R., Zhao, Y., Wang, Z., Liu, Z., Huang, M., Zeng, Q.: Recent advances and strategies in process and strain engineering for the production of butyric acid by microbial fermentation. Bioresour. Technol. (2018). https://doi.org/10. 1016/j.biortech.2018.01.007
17. Agrarmeteorologie Baden-Wemberg: Wetterstation Unterer Lindenhof. https://www.wetter-bw.de/Internet/AM/NotesBwAM. nsf/bwweb/7b6dc2ff140f6662c1257db2002d5120?OpenDocu ment\&TableRow=3.1.3,3.6\#3.1. $(2021)$

18. German Agricultural Society: Guideline for Testing of Silage Additives on DLG Quality Mark Capability (2013)

19. Auerbach, H., Eise, M., Hng, K., Ler, C., Nußbaum, H., Ostertag, J., Pahlow, G., Pauly, T., Rahn, S., Richter, W., R, G., Rubenschuh, U., Spiekers, H., Staudacher, W., Sum, K.-H., Thaysen, J., Tr, A., Wyss, U.: DLF Testing Guidelines. for the award and use of the DLG Quality Mark for ensiling agents. DLG TestService GmbH, 64823 Groß-Umstadt, Germany. https://www.dlg.org/fileadmin/downloads/tests/guetezeich en/DLG_Pruefrichtlinien_Siliermittel_ENG_kurz_2018.pdf (2018). Accessed 3 December 2018

20. Association of German Engineers: Fermentation of organic materials: Characterisation of the substrate, sampling, collection of material data, fermentation tests. Beuth Verlag $\mathrm{GmbH}$, Berlin (2006)

21. Helffrich, D., Oechsner, H.: The Hohenheim biogas yield test. Comparison of different laboratory techniques for the digestion of biomass. Agrartechnische Forschung 9, 27-30 (2003)

22. Weißbach, F., Strubelt, C.: Correcting the Dry Matter Content of GRass Silages as a Substrate for Biogas Production, pp. 210 211. Landtechnik (2008)

23. The Commission of the European Communities: COMMISSION REGULATION (EC) No 152/2009 of 27 January 2009 laying down the methods of sampling and analysis for the official control of feed (2009)

24. Federation of German Agricultural Investigation and Research Institutes (VDLUFA): The Chemical Analysis for Feedstuffs. Method Book III. VDLUFA, Darmstadt (2012)

25. R Core Team: R: A language and environment for statistical computing. R Foundation for Statistical Computing, Vienna (2018)

26. RStudio Team: RStudio: Integrated Development Environment for R. RStudio Inc., Boston (2016)

27. de Mendiburu, F.: agricolae: Statistical Procedures for Agricultural Research (2017)

28. Wickham, H. (ed.): ggplot2: elegant graphics for data analysis. Springer, New York (2016)

29. Haag, N.L., Grumaz, C., Wiese, F., Kirstahler, P., Merkle, W., Nägele, H.-J., Sohn, K., Jungbluth, T., Oechsner, H.: Advanced green biorefining. Effects of ensiling treatments on lactic acid production, microbial activity and supplementary methane formation of grass and rye. Biomass Conv. Bioref. (2016). https:// doi.org/10.1007/s13399-015-0178-2

30. LUFA Nord-West. https://www.lufa-nord-west.de/index.cfm/ action/downloadcenter?file $=0$ DEFC3DA (2020). Accessed 30 Oct 2020

31. Kim, S.C., Adesogan, A.T.: Influence of ensiling temperature, simulated rainfall, and delayed sealing on fermentation characteristics and aerobic stability of corn silage. J. Dairy Sci. (2006). https://doi.org/10.3168/jds.S0022-0302(06)72586-3

32. Muck, R.E., Moser, L.: PITT, R.E.: Postharvest factors affecting ensiling. Agronomy 42, 251-304 (2003)

33. Coblentz, W., Hoffman, P., Undersander, D.: Heat damaged forages: effects on forage energy content. Focus Forage 13, 4 (2011)

34. Bolsen, K.K., Ashbell, G., Weinberg, Z.G.: Silage fermentation and silage additives - review Asian-Australas. J. Anim. Sci. (1996). https://doi.org/10.5713/ajas.1996.483

35. Driehuis, F., Oude Elferink, S.J.W.H., van Wikselaar, P.G.: Fermentation characteristics and aerobic stability of grass silage inoculated with Lactobacillus buchneri, with or without 
homofermentative lactic acid bacteria. Grass Forage Sci. (2001). https://doi.org/10.1046/j.1365-2494.2001.00282.x

36. Oude Elferink, S.J., Krooneman, J., Gottschal, J.C., Spoelstra, S.F., Faber, F., Driehuis, F.: Anaerobic conversion of lactic acid to acetic acid and 1,2-propanediol by Lactobacillus buchneri. Appl. Environ. Microbiol. (2001). https://doi.org/10.1128/AEM. 67.1.125-132.2001

37. McEniry, J., Allen, E., Murphy, J.D., O’Kiely, P.: Grass for biogas production. The impact of silage fermentation characteristics on methane yield in two contrasting biomethane potential test systems. Renew. Energy (2014). https://doi.org/10.1016/j. renene.2013.09.052

38. Zhang, C., Yang, H., Yang, F., Ma, Y.: Current progress on butyric acid production by fermentation. Curr. Microbiol. (2009). https://doi.org/10.1007/s00284-009-9491-y
39. Li, Q.-Z., Jiang, X.-L., Feng, X.-J., Wang, J.-M., Sun, C., Zhang, H.-B., Xian, M., Liu, H.-Z.: Recovery processes of organic acids from fermentation broths in the biomass-based industry. J. Microbiol. Biotechnol. (2016). https://doi.org/10. 4014/jmb.1505.05049

40. Wu, D., Chen, H., Jiang, L., Xu, C.A.I.J., CEN, Z.: Efficient separation of butyric acid by an aqueous two-phase system with calcium chloride. Chin. J. Chem. Eng. (2010). https://doi.org/10. 1016/S1004-9541(10)60255-8

Publisher's Note Springer Nature remains neutral with regard to jurisdictional claims in published maps and institutional affiliations. 